\title{
Atypical Virchow-Robin Spaces Mimicking Cystic Primary Brain Tumor - Clinical Report and Literature Review
}

\section{Espaços perivasculares atípicos de Virchow-Robin simulando neoplasia primária do sistema nervoso central - Série de casos e revisão de literatura}

\author{
Helder Picarelli ${ }^{10}$ Thales Bhering Nepomuceno ${ }^{20}$ Yuri Casal ${ }^{30}$ Vitor Nagai Yamaki2 ${ }^{20}$ \\ Manoel Jacobsen Teixeira ${ }^{20}$ Eberval Gadelha Figueiredo ${ }^{20}$
}

\footnotetext{
${ }^{1}$ Division of Neurosurgery, Instituto do Câncer do Estado de São Paulo, São Paulo, SP, Brazil

2 Division of Neurosurgery, Hospital das Clínicas, Faculdade de Medicina, Universidade de São Paulo, São Paulo, SP, Brazil

${ }^{3}$ Division of Anatomical Pathology, Hospital das Clínicas, Faculdade de Medicina, Universidade de São Paulo, São Paulo, SP, Brazil
}

\begin{abstract}
Address for correspondence Helder Picarelli, MD, Divisão de Neurocirugia, Instituto do Câncer do Estado de São Paulo (ICESP), Rua Itacolomi, 538, apartamento 121, Higienópolis, São Paulo, SP, 01239-020, Brazil

(e-mail: helder.picarelli@hc.fm.usp.br; hpicarelli@gmail.com).
\end{abstract}

Arq Bras Neurocir 2020;39(4):311-316.

\begin{abstract}
Keywords

- virchow-robin space

- enlarged perivascular space

- atypical virchowrobin space

- cystic brain tumor
\end{abstract}

\section{Resumo}

The Virchow-Robin spaces (VRSs), which are often incidentally observed in modern structural neuroimaging examinations, are small cystic cavities that usually surround the small arteries and arterioles at the level of basal ganglia, the anterior perforated substance and the thalamic-mesencephalic junction. Typically, they have similar physicochemical characteristics to cerebral spinal fluid (CSF) and there is no contrast enhancement on brain CT and MRI images. Its real meaning is unknown, although some contemporary studies have suggested that it might be related to certain traumatic brain injury or several other central nervous system (CNS) disorders, as degenerative diseases. Occasionally, some wide and atypical VRS may be mistaken for primary cystic brain tumors, especially in the context of large and symptomatic lesions, multiple clustered cysts, cortical lesions and if there is adjacent reactive gliosis. The present paper reports four patients who were affected by atypical VRS mimicking brain tumors that required imaging follow-up or even a biopsy to confirm the diagnosis or to indicate the correct approach. Although it is not so unusual, one of them occurred concomitantly and adjacent to a diffuse glioma (co-deleted 1p19q, WHO-GII).

Os espaços perivasculares alargados de Virchow-Robin (EVRs), que são frequentemente observados incidentalmente nos modernos exames estruturais de neuroimagem como pequenas cavidades císticas, geralmente circundam as pequenas artérias e arteríolas ao nível dos gânglios da base, da substância perfurada anterior e da junção tálamo-mesencefálica. Normalmente, eles têm características físico-químicas semelhantes às do líquido received February 19, 2020 accepted July 7, 2020
DOI https://doi.org/ 10.1055/s-0040-1716562. ISSN 0103-5355.
Copyright $\odot 2020$ by Thieme Revinter

Publicações Ltda, Rio de Janeiro, Brazil
License terms

(요 (1) $\Theta$ 


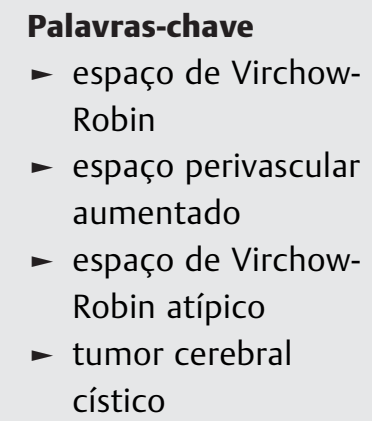

cefalorraquidiano e não apresentam realce após a injeção de contraste iodado ou paramagnético nas imagens obtidas por tomografia ou ressonância magnética de crânio. O significado real desse achado é desconhecido, embora alguns estudos contemporâneos tenham sugerido que eles possam estar relacionados a certas lesões cerebrais traumáticas ou a vários outros distúrbios do sistema nervoso central (CNS), como algumas doenças degenerativas. Ocasionalmente, alguns EVRs volumosos e atípicos podem ser confundidos com tumores cerebrais primários císticos, especialmente no contexto de lesões grandes e sintomáticas, cistos agrupados múltiplos, lesões corticais e se houver gliose reativa adjacente. $\mathrm{O}$ presente artigo relata quatro pacientes portadores de EVR atípicos, mimetizando tumores cerebrais, que necessitaram de acompanhamento com imagens seriadas ou até uma biópsia para confirmar o diagnóstico ou indicar o tratamento adequado. Embora não seja tão incomum, um deles ocorreu concomitantemente e adjacente a um glioma difuso (co-deletado 1p19q, OMS-GII).

\section{Introduction}

The Virchow-Robin spaces (VRSs), or perivascular spaces, are small cystic cavities that usually surround the walls of arteries, arterioles, veins and venules at the level of the basal ganglia, the anterior perforated substance and the thalamic-mesencephalic junction, as they course from the subarachnoid space through the brain parenchyma. ${ }^{1-4}$ These spaces, which are better visualized in magnetic resonance imaging (MRI) T2weighted images, are considered to be enlarged when the size exceeds $2 \mathrm{~mm}$. Typically, its physicochemical characteristics are similar to the cerebral spinal fluid (CSF), there is no contrast enhancement and the tissues surrounding it are totally normal on brain computed tomography (CT) and MRI images. Commonly, they are asymptomatic and are found in all age groups, although the frequency with which they are observed increases with age. Although some contemporary studies have suggested that it might be related to certain traumatic brain injury and several other central nervous system (CNS) disorders, its real meaning is unknown. ${ }^{5-24}$

Occasionally, some enlarged VRSs can reach a very large volume, assume bizarre settings and have reactional gliosis surrounding them. In these particular conditions they are socalled atypical and tumefactive VRSs and may present themselves with symptoms such as seizures, hydrocephalus and headache. Most often, atypical and tumefactive VRSs are difficult to differentiate from a couple of pathologic conditions, especially from some primary cystic brain tumors and vascular disorders. Sometimes, either follow-up over time with serial imaging or a biopsy is needed to establish the correct diagnosis and the most appropriate management. ${ }^{1-11,25}$

\section{Case Reports}

\section{Case 1}

A 25-year-old female patient, without any past medical history, was admitted to the service complaining of early onset of short focal seizures with fast bilateral tonic clonic progression. In that time, her clinical history and semiology features were very suggestive of frontal lobe epilepsy and her neurological exami- nation was unremarkable. The brain MRI images showed multiple small cystic lesions, in the cortex and in the white matter of the superior and middle frontal gyri, with intensities similar to the CSF ( - Fig. 1). Faced with diagnostic hypotheses of symptomatic epilepsy, triggered by atypical enlarged VRS or multinodulated vacuolar neuronal tumor or other cystic glioma tumor, the patient underwent surgical treatment. We have performed an awake craniotomy - with brain mapping - which was successful and got subtotal resection without any functional impairment. The histopathological workup showed a wide VRS around capillary vessels with normal surrounding tissue. On the immunohistochemical analysis, the tissue was positively marked for Neu-N and CD34 delineating the vascular contour (-Fig. 2).

\section{Case 2}

A 38-year-old male patient was submitted to brain CT and MRI after mild accidental traumatic brain injury. The MRI revealed small cystic lesions on T2-weighted in the cingulate gyrus of the right frontal lobe without diffusion restriction (-Fig. 3). There was no perilesional edema on fluid attenuation inversion recovery (FLAIR) and no contrast enhancement. The patient has been followed-up for 6 years and remains asymptomatic. His periodic brain images have not shown any progression of the lesions, which strongly suggests the diagnosis of atypical VRS.

\section{Case 3}

A 49-year-old female patient was admitted to our service with reentrant epileptic seizures. In her past medical history, it was reported that she had diabetes, hypertension, and drug-resistant epilepsy for 10 years secondary to a right frontal lobe lesion. She had been previously submitted to a stereotactic biopsy in an external service with inconclusive findings. She underwent an MRI that revealed a small right frontal lesion, with hyperintense signal on FLAIR and T2-weighted images, mild hyperintense signal on T1 images, reasonable diffusion restriction, infiltrative behavior, minor mass effect and no contrast enhancement. Adjacent to these, there were multiple 


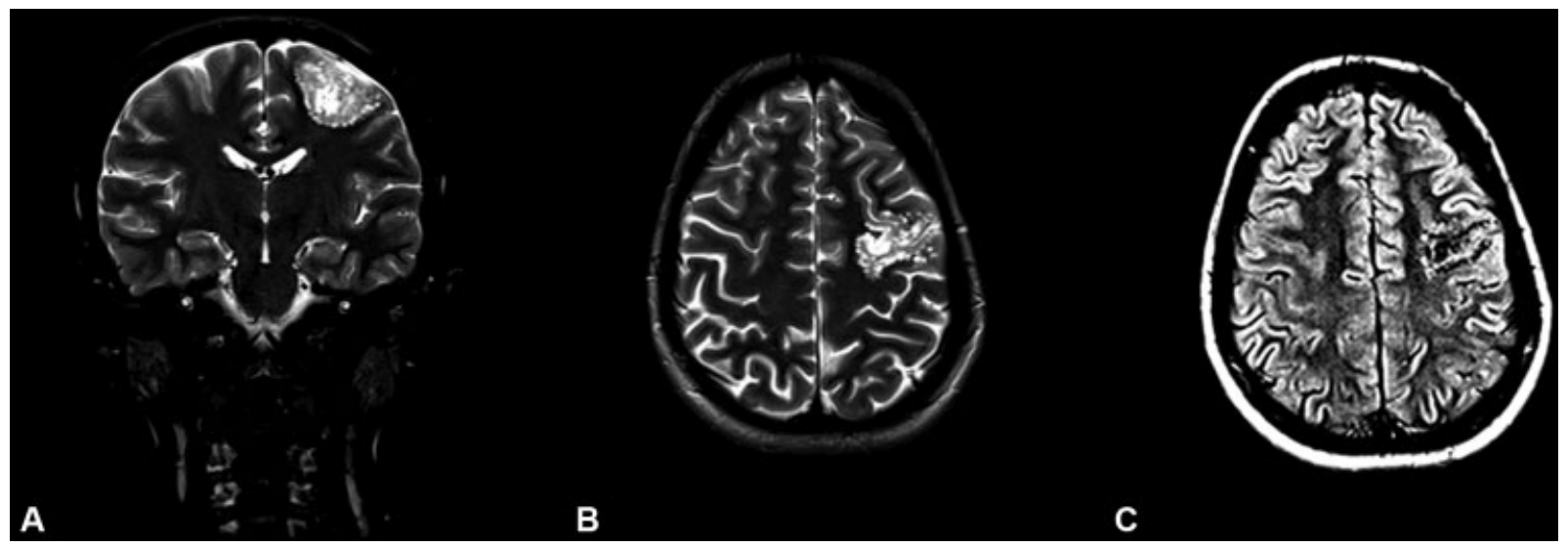

Fig. 1 Case 1. Type 2 atypical enlarged VRS in the cerebral convexity mimicking a cystic primary tumor. The MRI of the brain demonstrates a cystic lesion on the left frontal lobe. Visually, the signal intensity of the cystic contents is identical to those of CSF with all pulse sequences. The sign intensity of the brain parenchyma surrounding is slightly higher than the normal tissue and there is no gadolinium enhancement. (A) Coronal T2-weighted image, (B) Axial T2-weighted brain slice, (C) Axial fluid-attenuated inversion-recovery (FLAIR) view.
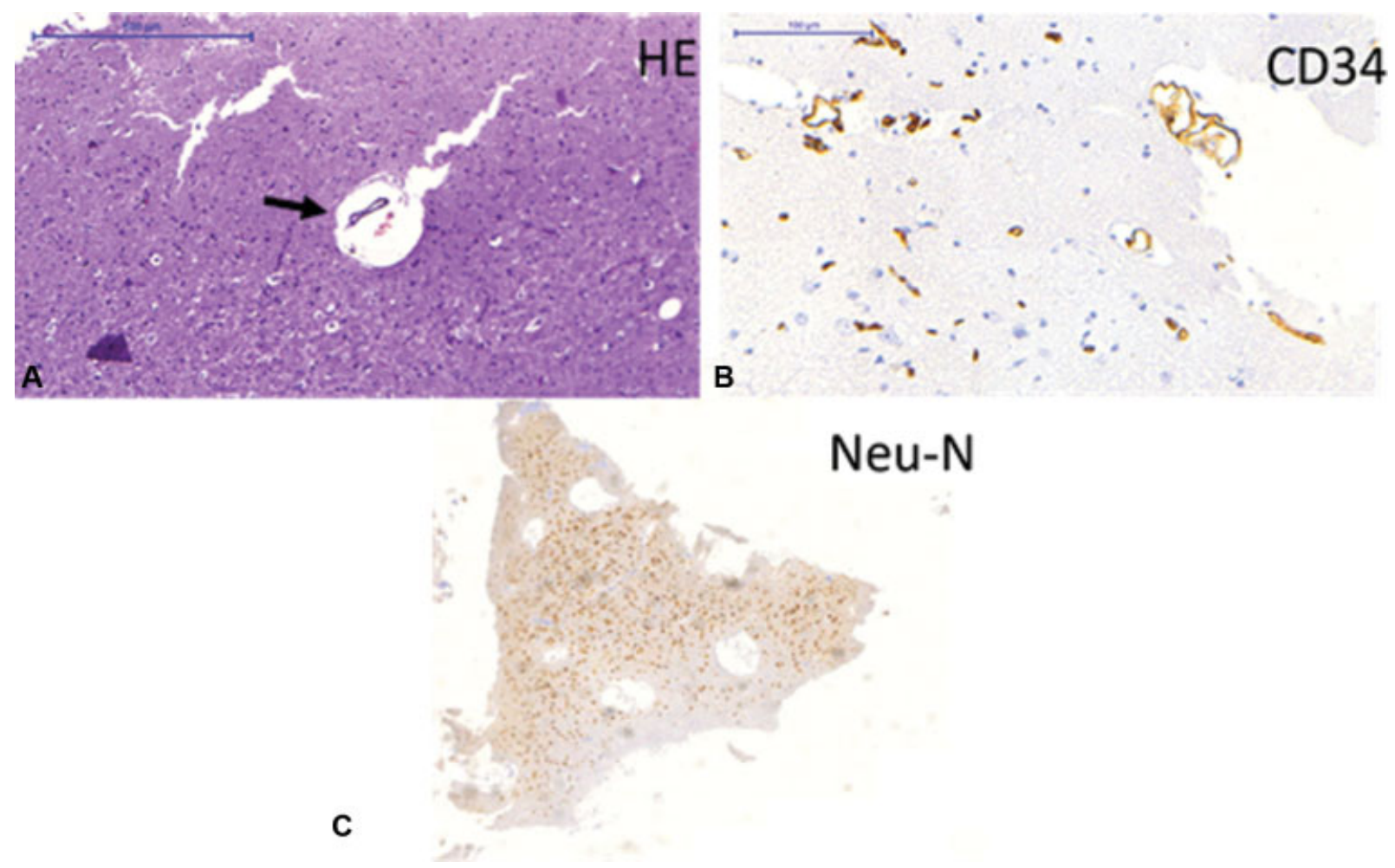

Fig. 2 Histological characterization of the enlarged Virchow Robin Space. (A) photomicrograph showing cystic dilation of the Virchow-Robin space around a capillary vessel (arrow). Surrounding the dilatation, normal brain tissue is observed. (B): photomicrograph showing immunohistochemical marker (CD34) delineating the vascular contour within a cystic dilation (arrow). (C): NeuN showing normal neuronal organization in the brain parenchyma.

clustered cysts with signal very similar to CSF located in the frontal, temporal, insular and parietal lobes; without restriction to the movement of water molecules in the diffusion sequence, also without contrast enhancement ( - Fig. 4). The patient was submitted to surgical treatment for resection of those cystic lesions that were compatible with VRS on histopathological analysis. In addition to this procedure, we have performed a subtotal surgical resection of the infiltrative lesion that, in the histopathological exam, was compatible with oligodendroglioma (Grade II - World Health Organization
[WHO]) with the $1 \mathrm{p} 19 \mathrm{q}$ codeletion and $\mathrm{K}_{\mathrm{i}}-67$ of $2 \%$. The immunohistochemistry stains were positive for glial fibrillary acidic protein (GFAP) and negative for synaptophysin.

\section{Case 4}

An 8-year-old male patient, who has been affected by epilepsy for a year, has just started his follow-up treatment in our service. The seizures were easily controlled with levotiracetam and his brain MRI images revealed small cystic lesions on T2-weighted in the right occipital lobe without 


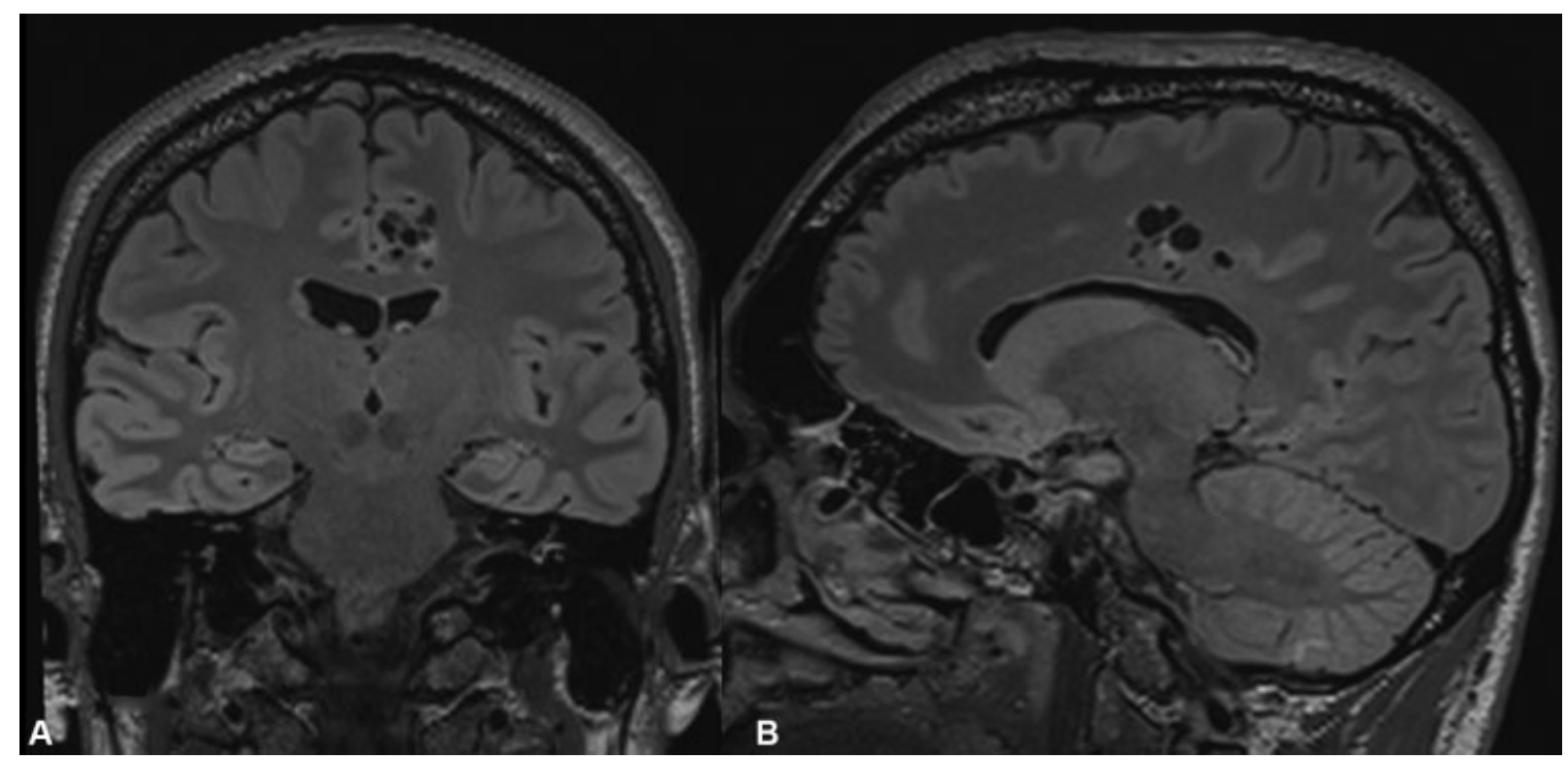

Fig. 3 Case 2. Type 2 atypical enlarged VRS, in the left anterior cingulate gyrus, that could be misdiagnosed as a cystic primary tumor. The FLAIR images show that cystic contents, as well the neighboring cerebral cortex, have identical signal intensity to those of CSF and the normal brain cortex, respectively. The appearance of cystic lesions aligned with white matter tracts and with the perimedulary veins strongly suggests an atypical enlarged VRS diagnosis and it was also reinforced by the stability of the findings for 6 years (A) Coronal FLAIR view, (B) Sagital FLAIR image.

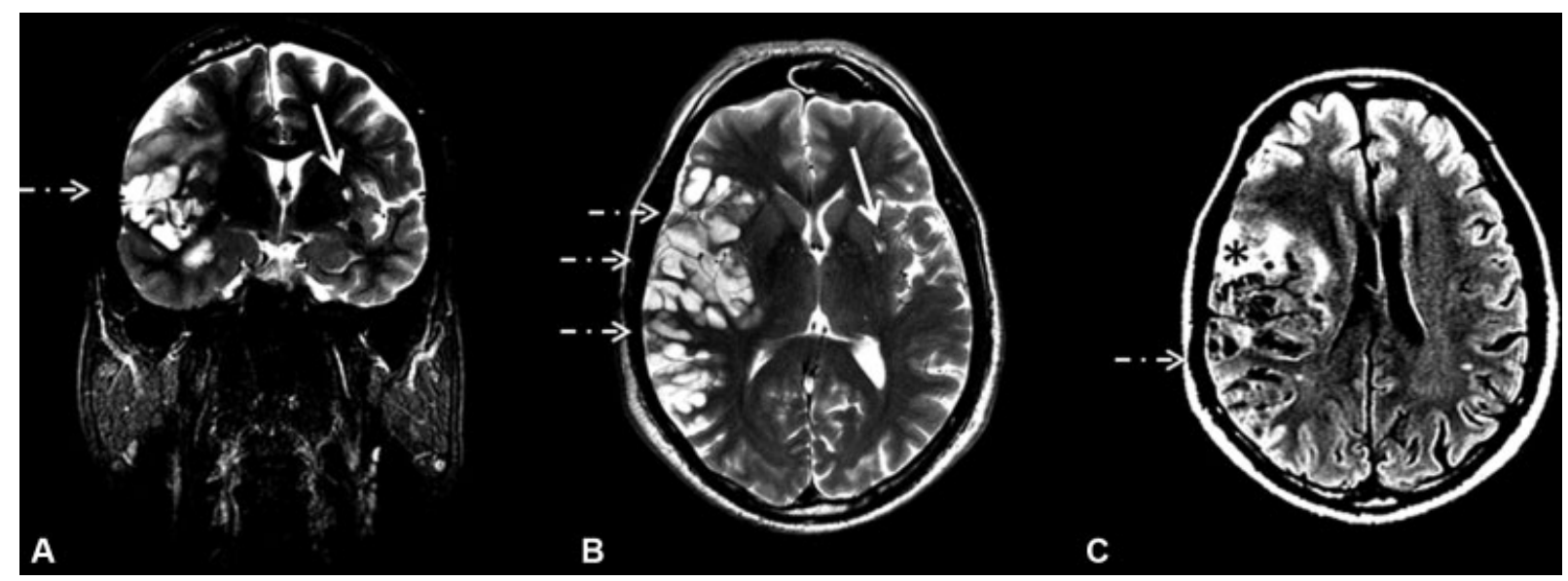

Fig. 4 Case 3. Tumefactive VRS located adjacent to an oligodendroglial tumor. The MRI demonstrates multiple tumefactive perivascular spaces of various sizes in the right frontal, insular and temporal lobes adjacent to a suspected T2-hyperintense frontal area which has T1 hyposignal and no enhancement after contrast. The anatomopathological study of the whole lesion was consistent with enlarged VRS adjoining a 1p/19q codeleted oligodendroglial tumor. (A) Coronal T2-weighted view, (B) Axial T2-weighted image, (C) Axial FLAIR image. $\downarrow$ Typical enlarged VRS -.- > Atypical enlarged VRS * 1p/19q codeleted oligodendroglioma tumor.

diffusion restriction (-Fig. 5). There was no perilesional edema on FLAIR and no contrast enhancement. The patient remains with good seizure control and he has been followedup for 4 years. His periodic brain images have not shown any progression of the lesions, which is consistent with the diagnosis of atypical VRS.

\section{Discussion}

The VRSs are perivascular cystic cavities $(2-3 \mathrm{~mm})$ with a CSF-like component filling inside within the brain parenchyma. ${ }^{1-3}$ Those anatomic landmarks are observed in between 50 and $100 \%$ on MRI structural images depending on the age of the patient and MRI resolution. ${ }^{1-3}$ These spaces charac- terized by direct communication with subpial spaces are covered by a double layer of piamater and have no communication with the subarachnoid compartment. ${ }^{2-4,17}$ Studies with target radiotracers have shown that VRS has an important role for the drainage of liquids and solute content from the gray matter, which reaching those perivascular spaces, from the extracellular compartment through passive diffusivity, works as a lymphatic pathway of the brain. Besides that, the VRS has a specific macrophagic population that might be enrolled with some immunologic functions, even though it has not been well documented. ${ }^{1-4,17,20}$

The enlarged VRS is defined as perivascular spaces wider than $3 \mathrm{~mm}$, which are rarely located on the cortical surface and are often found in the inferior portion of the basal ganglia, 


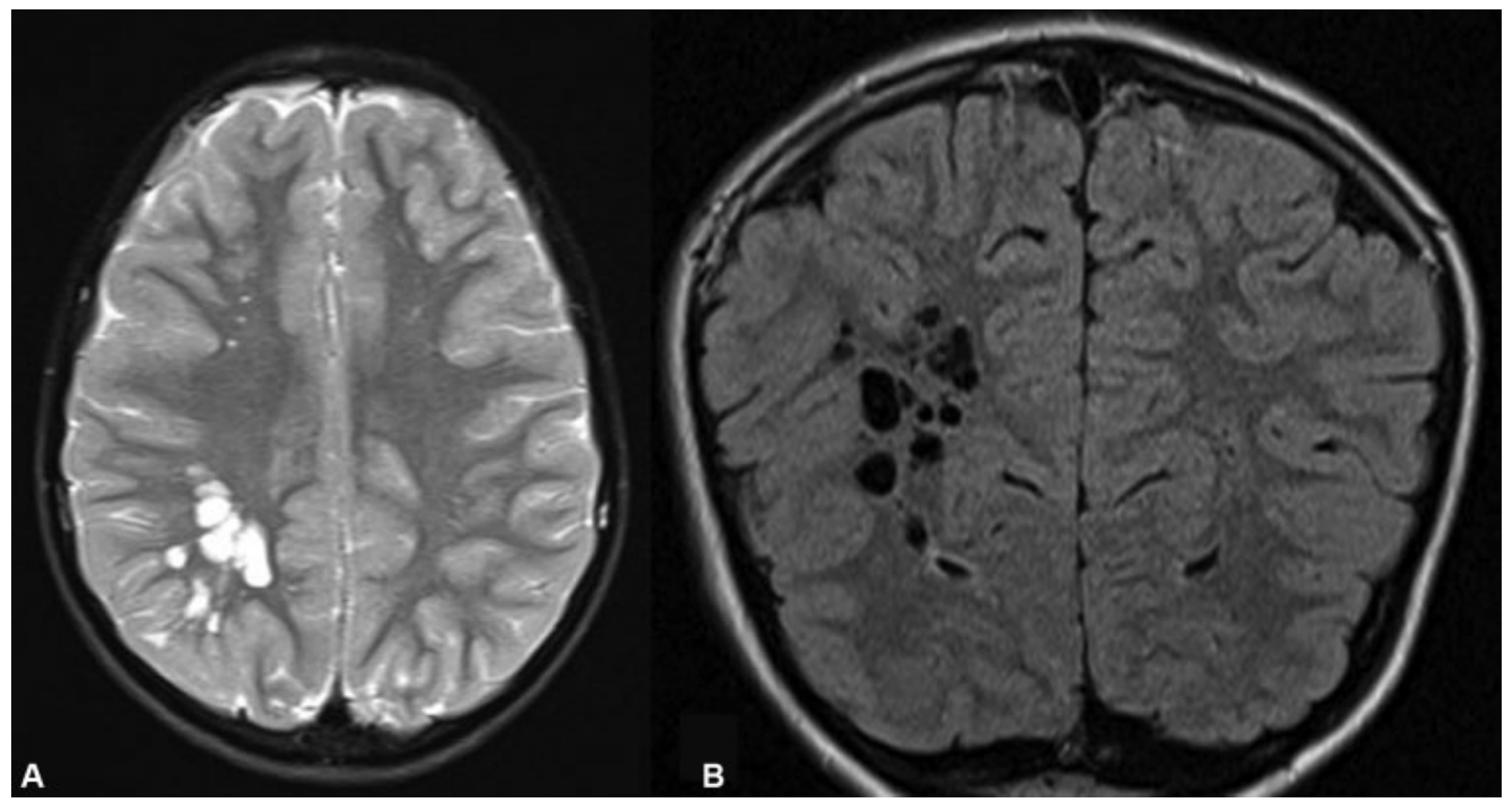

Fig. 5 Case 4. Type 2 atypical enlarged VRS, in the right occipital lobe. (A) Axial T2-weighted image shows linear to cystic hyperintense areas around the right occipital horn. The signal intensity of the surrounding brain parenchyma is normal; (B) Coronal Flair image shows that the spot has CSF-like content. In some areas, around the cystic lesions, there is a thin layer with hyperintense signal, and its appearance reflects gliosis, which is unusual.

especially in the anterior perforated substance or even in the anterior commissure, the substantia nigra, the dentate nucleus, the corpus callosum and the cingulate gyrus. ${ }^{2-12,14}$ A study evaluation with high-resolution MRI from 125 healthy subjects reported an occurrence of $100 \%$ and $1.6 \%$ of VRS and wide VRS, respectively. ${ }^{2}$ It has been hypothesized a positive correlation between those enlarged VSRs with a wide variety of neurological diseases such as psychiatric disorders, dementia, cognitive disturbances, multiple sclerosis, brain trauma and microvascular anomalies of the brain. ${ }^{13-21}$

On MRI, the VRS shares similar characteristics to CSF, that is, hypointense signal in T1- and hyperintense signal on T2weighted images. ${ }^{1-4,19-23}$ There is no restriction to diffusion, no gadolinium enhancement, and a suppressed signal on FLAIR sequences. Occasionally, the white matter surrounding those perivascular spaces might present a marked gliosis. On coronal and sagittal views, the VRS might assume a radial linear or curvilinear appearance, since it follows the trajectory of blood vessels, especially of medullary arteries. Grouped VRS on MRI are named "État Criblé" or "Status Cribosum" since it has similar appearance to a sieve..$^{1-4,19-23}$ On brain CT, it might be identified as CSF-like cystic lesions, without calcifications or contrast enhancement. ${ }^{1-4,19-23}$

These enlarged VRSs might be classified in three types: Type 1, the lenticulostriate arteries are involved at the level of the basal ganglia and anterior perforated substance; Type 2 , if it is located around the medullary veins of the brain, in the superficial cortical region or in the white matter surrounding it; Type 3, when the VRS is located close to the brainstem, around the mesencephalic vessels, especially at the level of the thalamomesencephalic junction.,20

When very wide, the VRS are called tumefactive perivascular spaces. ${ }^{7,13,23}$ A special variant of this, which sometimes can mimic cystic brain tumors, was recently described and named anterior temporal lobe perivascular space. Most often, this entity is associated with a looping of a branch of the middle cerebral artery as well as with a focal region of cortical thinning or nonexistent. ${ }^{13,23}$ Even though enlarged VRS or tumefactive perivascular spaces may have some degree of gliosis or minor expansive effect, rarely any symptoms can be attributed to them.

The so-called atypical VRSs are enlarged perivascular spaces which really present very large volumes or still take the form of voluminous multiple clustered cysts. Although they may occur in the cerebral convexity cortex and be multifocal or bilateral, atypical VRSs commonly are solitary and occur in the brainstem, notably in the thalamic-encephalic junction. Unlike the other mentioned variants of perivascular spaces, atypical cases are often accountable for symptoms such as headache, nausea, vomiting, seizures and drowsiness. The main mechanisms involved in it are mass effect, perilesional edema, gliosis and CSF flow disturbances caused by the distortion of the Sylvius aqueduct and of the third ventricle, with consequent hydrocephalus. 3,6-12,20,22,23

Magnetic resonance imaging, with advanced imaging technique, is considered the gold standard approach for VRS diagnosis and it permits the certainty of diagnosis in most cases. Differential diagnosis includes arachnoid cysts, neuroepithelial cysts, lacunar stroke, multicystic encephalomalacia, neurocysticercosis, neurocriptococcosis and cystic brain tumors. Considering the above, usually arachnoid cysts are also asymptomatic and there is no contrast enhancement; inflammatory diseases present marked contrast enhancement and CSF laboratory changes; neurocysticercosis have a nodular component inside the cysts and usually come with parenchymal calcifications; and vascular disorders are associated with 
sudden symptoms in elderly people who have other risk factors for stroke. ${ }^{5-10,16-20,22-25}$

Despite advanced MRI techniques, sometimes it is still difficult to differentiate VRS from some cystic brain tumors. Often, the density of the cystic contents of brain tumors is slightly different from the one found in CSF, which frequently help for a differential. In addition, brain tumors usually have indolent symptoms, mass effect and perilesional edema. Although MRI usually clarifies the diagnosis, a biopsy or even a surgical resection might be required for some atypical cases to have the diagnosis of certain stablished or to have the symptoms under control. We have decided for surgical approach on case 1 and 3 just to have the accurate diagnosis and to get seizure control. In those cases, we also understood that obtaining a sample of tissue was important to differentiate enlarged VRS from low-grade glioma and vacuolating multinodular neural tumor. The last, which is described as an indolent neoplasm related to late-onset epilepsy, was recently recognized as a new entity by the 2016 WHO classification, and they behave more as a dysplastic/malformative lesion than as a true neoplasm with origin from a progenitor type with origin from a progenitor neuroglial cell type showing aberrant maturation. ${ }^{25}$

\section{Conflict of Interests}

The authors have no conflict of interests to declare.

\section{References}

1 Glick Y, Gaillard F, et al. . Perivascular spaces. Radiopaedia.org. Available in: https://radiopaedia.org/articles/perivascular-spaces (accessed in August 1, 2019)

2 Groeschel S, Chong WK, Surtees R, Hanefeld F. Virchow-Robin spaces on magnetic resonance images: normative data, their dilatation, and a review of the literature. Neuroradiology 2006; 48(10):745-754. Doi: 10.1007/s00234-006-0112-1

3 Kwee RM, Kwee TC. Virchow-Robin spaces at MR imaging. Radiographics 2007;27(04):1071-1086. Doi: 10.1148/rg.274065722

4 Song CJ, Kim JH, Kier EL, Bronen RA. MR imaging and histologic features of subinsular bright spots on T2-weighted MR images: Virchow-Robin spaces of the extreme capsule and insular cortex. Radiology 2000;214(03):671-677. Doi: 10.1148/radiology.214.3. r00mr17671

5 Jungreis CA, Kanal E, Hirsch WL, Martinez AJ, Moossy J. Normal perivascular spaces mimicking lacunar infarction: MR imaging. Radiology 1988;169(01):101-104. Doi: 10.1148/radiology.169.1.3420242

6 Poirier J, Barbizet J, Gaston A, Meyrignac C. [Thalamic dementia. Expansive lacunae of the thalamo-paramedian mesencephalic area. Hydrocephalus caused by stenosis of the aqueduct of Sylvius]. Rev Neurol (Paris) 1983;139(05):349-358

7 Salzman KL, Osborn AG, House P, et al. . Giant tumefactive perivascular spaces. AJNR Am J Neuroradiol 2005;26(02):298-305

8 Kanamalla US, Calabrò F, Jinkins JR. Cavernous dilatation of mesencephalic Virchow-Robin spaces with obstructive hydrocephalus. Neuroradiology 2000;42(12):881-884. Doi: 10.1007/ s002340000440
9 Papayannis CE, Saidon P, Rugilo CA, et al. . Expanding Virchow Robin spaces in the midbrain causing hydrocephalus. AJNR Am J Neuroradiol 2003;24(07):1399-1403

10 Rohlfs J, Riegel T, Khalil M, et al. . Enlarged perivascular spaces mimicking multicystic brain tumors. Report of two cases and review of the literature. J Neurosurg 2005;102(06):1142-1146. Doi: $10.3171 /$ jns.2005.102.6.1142

11 Longatti PL, Fiorindi A, Carteri A, Caroli F, Martinuzzi A. Expanding cerebral cysts (lacunae): a treatable cause of progressive midbrain syndrome. J Neurol Neurosurg Psychiatry 2003;74(03):393-394. Doi: $10.1136 /$ jnnp.74.3.393-a

12 House P, Salzman KL, Osborn AG, MacDonald JD, Jensen RL, Couldwell WT. Surgical considerations regarding giant dilations of the perivascular spaces. J Neurosurg 2004;100(05):820-824. Doi: $10.3171 /$ jns.2004.100.5.0820

13 Rawal S, Croul SE, Willinsky RA, Tymianski M, Krings T. Subcortical cystic lesions within the anterior superior temporal gyrus: a newly recognized characteristic location for dilated perivascular spaces. AJNR Am J Neuroradiol 2014;35(02):317-322. Doi: 10.3174/ajnr.A3669

14 Barkhof F. Enlarged Virchow-Robin spaces: do they matter? J Neurol Neurosurg Psychiatry 2004;75(11):1516-1517. Doi: 10.1136/jnnp. 2004.044578

15 Maclullich AMJ, Wardlaw JM, Ferguson KJ, Starr JM, Seckl JR, Deary IJ. Enlarged perivascular spaces are associated with cognitive function in healthy elderly men. J Neurol Neurosurg Psychiatry 2004;75(11):1519-1523. Doi: 10.1136/jnnp.2003.030858

16 Patankar TF, Mitra D, Varma A, Snowden J, Neary D, Jackson A. Dilatation of the Virchow-Robin space is a sensitive indicator of cerebral microvascular disease: study in elderly patients with dementia. AJNR Am J Neuroradiol 2005;26(06):1512-1520

17 Gess B, Niederstadt TU, Ringelstein EB, Schäbitz WR. [Clinical relevance of normal and enlarged Virchow-Robin spaces]. Nervenarzt 2010;81(06):727-733. Doi: 10.1007/s00115-010-2983-y

18 Al-Saeed O, Athyal R, Ismail M, Sheikh M. Significance of VirchowRobin spaces in patients newly diagnosed with multiple sclerosis: a case-control study in an Arab population. Med Princ Pract 2012; 21(05):447-451. Doi: 10.1159/000337427

19 Soumya MS, Rajendran VR, Saanida MP, Gomathy S, Rajan P, Aryasree PM. Role of MRI in asymptomatic and symptomatic Virchow Robin spaces. Eurorad.org. Available in: https://www.eurorad.org/case/ 13472 (accessed in august 2, 2019). Doi: 10.1594/EURORAD/ CASE.13472

20 Kwee RM, Kwee TC. Tumefactive Virchow-Robin spaces. Eur J Radiol 2019;111:21-33. Doi: 10.1016/j.ejrad.201812.011

21 Heier LA, Bauer CJ, Schwartz L, Zimmerman RD, Morgello S, Deck MD. Large Virchow-Robin spaces: MR-clinical correlation. AJNR Am J Neuroradiol 1989;10(05):929-936

22 Lim AT, Chandra RV, Trost NM, McKelvie PA, Stuckey SL. Large anterior temporal Virchow-Robin spaces: unique MR imaging features. Neuroradiology 2015;57(05):491-499. Doi: 10.1007/ s00234-015-1491-y

23 Buell TJ, Ramesh A, Ding D, et al. . Dilated Virchow-Robin Spaces Mimicking a Brainstem Arteriovenous Malformation. J Neurosci Rural Pract 2017;8(02):291-293. Doi: 10.4103/0976-3147.203826

24 Jhawar SS, Garewal SS, Bhargava P, Nittala PP. Dilated Virchow Robin spaces mimicking cystic neoplasm of cingulated gyrus. Neurol India 2012;60(01):136-137. Doi: 10.4103/0028-3886.93595

25 Thom M, Liu J, Bongaarts A, et al. . Multinodular and vacuolating neuronal tumors in epilepsy: dysplasia or neoplasia? Brain Pathol 2018;28(02):155-171. Doi: 10.1111/bpa.12555 